\title{
Individual Time Perspective And Alliance Formation Behavior
}

\author{
Peg Thoms, (E-mail: mat6@psu.edu), Penn State Erie \\ Alfred G. Warner, (E-mail: agw2@psu.edu, Penn State Erie \\ Janice A. Totleben, (E-mail: jat14@psu.edu), Penn State Erie
}

\begin{abstract}
The impact of time orientation on leaders' behavior has been largely unexplored in research. This study examined the role of time perspective in alliance formation. Using a game, participants formed alliances using information about past behavior. Findings suggest that participants with future time perspective were more likely to initiate alliances and those with a past-negative perspective were more likely to cooperate. This finding supports the Theory of Leadership and Time Orientation.
\end{abstract}

\section{BACKGROUND}

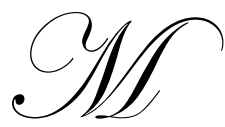

uch recent leadership literature has emphasized the importance of having a future time orientation (Bass, 1985; Burns, 1978; House, 1971; House, 1977). For the past twenty years, this has also been the emphasis in leadership books geared toward practitioners (e.g. see Bennis \& Nanus, 1985; Kouzes \& Posner, 1995; Welch, 2001). This emphasis on the future-oriented leader has occurred despite a dearth of empirical evidence that a future time perspective is a critical trait. In contrast, scholars have argued that too little has been written about time perspective and behavior in organizational settings (Bluedorn \& Denhardt, 1988; Das, 1993; Zimbardo \& Boyd, 1999).

Thoms and Greenberger (1995) theorized that the time perspective necessary for effective leadership actually varies depending on the specific task and situation in which the leader is involved and suggested that past, present, and future time perspectives all have their place in leadership contingent on the problem and the level of decision making. They proposed that leaders must analyze and respond to situations with the appropriate orientation which suggests that in some cases, leaders may have to use conscious strategies for coping when the task calls for behavior that falls outside their individual orientation toward time. This might mean adjusting normal behavior or, if the bias for one orientation is too strong, it might involve bringing in a colleague who has the appropriate time orientation. One important function of leaders where understanding different time perspectives may be informative is in the contrast between generating new opportunities through alliances and managing existing alliances. Put differently, we are interested in understanding if and how time perspectives affect how managers behave in alliances.

Strategic alliances have become increasingly important to companies (Hergert \& Morris, 1987; Olk \& Elvira, 2001). Firms use alliances to access new technologies and knowledge, to exploit economies of scale, to share risk and, ultimately, to gain competitive advantage (Kale, Singh, \& Perlmutter, 2000). An alliance is a formal agreement between two or more organizations to undertake a set of private and common goals in contexts involving contested markets and uncertainty over outcomes. Because alliance almost always entails a risk of loss to the partner, managers implement governance structures to oversee the relationship. However, some alliance dyads may be able to minimize governance costs if the level of trust between them is sufficiently high enough to mitigate the need for oversight (Ariño, de la Torre, and Ring, 2001).

The purpose of this study was to test the relationships between individual time perspective and two types of leader behavior: initiating and cooperating (or building a reputation for trustworthiness) in transactions like alliance formation. We tested these relationships with data gathered from an iterative, on-line variant of the Prisoner's 
Dilemma game featuring temporary alliances and the ability to change player reputations over time. The results indicate that alliance formation and cooperative behavior are related to two different time orientations but that both may be useful in conducting alliances. The terms time orientation and time perspective have been used interchangeably in this article.

\section{LEADERSHIP AND TIME ORIENTATION}

Both the academic and lay leadership literatures have placed an emphasis on the need for visionary or future oriented leaders. Burns $(1978)$ and House $(1971,1977)$ emphasized the importance of leaders creating visions of the future for their organizations. Kouzes and Posner (1995) suggest that effective leaders are pulled forward by their visions of the future. Research has found that a future-orientation is important to long-range planning (Das, 1986, 1987; El Sawy, 1983) and is a critical component of the ability to create an organizational vision (Thoms \& Blasko, 1999; Thoms \& Greenberger, 1998).

The theory of Leadership and Time Orientation proposed that a present orientation toward time also has an important place in effective leadership depending on what the specific situation requires (Thoms and Greenberger, 1995). For example, present-oriented leaders would be effective in handling day-to-day operations, and handling issues as they occur so that work can continue in the short run. However, a great deal of psychological research has been done on present time orientation and its two subcategories, hedonism and fatalism, as they relate to high risk and anti-social behavior (e.g. see Keough, Zimbardo, \& Boyd, 1999). This line of psychological research emphasizes the negative aspects of a present orientation. No published empirical evidence could be found that emphasized the need or importance of a present time orientation for organizational leaders or managers.

The theory also proposed that a past orientation toward time provides leaders an advantage in a number of important functions. For example, problem solving and performance assessment require attention to the past. Several situational leadership theories also imply that it is important to reflect on past experiences in order to decide how to behave in specific situations (e.g. see Hersey \& Blanchard, 1969; Kerr \& Jermier, 1978; Vroom \& Jago, 1988). Drucker (1954) also emphasized the need to recapture the past in order to solve problems by recreating previous steps. In addition, Schein (1992) pointed to the importance and value of the history of an organization to the members and external stakeholders. Recapturing the past is also necessary to predict the future (Tversky \& Kahneman, 1973). Research has shown that the availability of past instances is a useful indicator of future events (Hogarth, 1987). Tversky and Kahneman (1973) found that accuracy improved as an individual used past instances as a basis for prediction. Nonetheless, recapturing the past is something that some leaders may choose not to do for a variety of reasons, including a lack of interest in the past. The past is not valued in American society (Jones, 1988) and particularly not by future-oriented people or those who believe that they should be future-oriented (Thoms, 2004).

Zimbardo and Boyd (1999) argue that time perspective exerts a dynamic influence on many important judgments, decisions, and actions. When talking specifically about a past time perspective, they suggest that, "The dominant influence for some comes from the past, from recalling analogous prior situations, with memory of the costs and benefits that attended those decisions. Their recall may be nostalgic and positive or ruminative, traumatic, aversive, and negative, and they may remember accurately or distort the past. Such a focus on the past can significantly affect the interpretation of and response to the current decision situation, even dominating its intrinsic stimulus (p. 1272).”

When a tendency develops to overemphasize the past, the present, or the future, it serves as a cognitive bias toward being past, future, or present oriented. This bias becomes a dispositional style or individual-differences variable that is predictive of how an individual will respond to life choices (Zimbardo and Boyd, 1999). The authors go on to suggest that time perspective is a relatively stable individual-differences process. In their general conceptual Model of Time Perspective, Zimbardo and Boyd (1999) found that time perspective falls into five factors: PastNegative reflects a generally negative view of the past; Past-Positive reflects a warm sentimental attitude toward the past; Present-Hedonistic reflects a hedonistic, risk-taking attitude toward time and life; Present-Fatalistic reflects a fatalistic, helpless, and hopeless attitude toward the future and life; and Future reveals a general future orientation. 


\section{ALLIANCES, TRUST, AND TIME PERSPECTIVE}

According to Ridley (1996), the origins of modern trade are rooted in the need to establish and preserve alliances for safety purposes. Ridley suggests that effective alliance building relies on trust which is established over time after a series of opportunities to observe a partner's behavior toward oneself and others. The more trust, the closer and more important the alliance. Trust can only be built over time by remembering past behavior which is critical to make accurate decisions about alliances. Thus, though business leaders initiate and sustain alliances for many reasons, superior alliance management should entail trust and reliability between partners.

Rousseau, Sitkin, Burt, and Camerer (1998) suggest that "trust is a psychological state consisting of the intention to accept vulnerability based upon positive expectations of the intentions or behavior of another," (p. 395). Sabel (1993, p. 1133) defines trust as "the mutual confidence that no party to an exchange will exploit another's vulnerabilities." Though Rousseau et al. (1998) are discussing trust between individuals and Sabel (1993) is referring to trust between organizations, at both levels the parties are vulnerable and must expose themselves to potential harm when alliances are formed. The duration, quality, and predictability of risks are elements of trust in any working relationship (Frink \& Klimoski, 1998).

Although management literature generally treats alliances at the organizational level, it is clear that trust actually emerges between individuals and exchanges between firms are often the purview of individuals or small groups (Barney \& Hansen, 1994). Barney and Hansen (1994), citing Zucker (1987), also suggest that a firm level reputation for trustworthiness can emerge from the role of firm founders or other influential firm members in creating the appropriate cultural values. The trustworthiness of leaders in the organizations making up an alliance plays the primary role in the process of building a strong partnership (Ring \& Van de Ven, 1992). Granovetter (1985) suggests that traditional economic analysis neglects the identity and past relations of individuals, but rational people know better and rely on their knowledge of these relations. He goes on to argue that most behavior is closely embedded in networks of interpersonal relations and that the key to understanding how existing organizations arrived at their current state is by an analysis of their social structure. Lewicki, McAllister, and Bies (1998) report that trust is a foundation for social order, within and beyond organizations, which has a significant impact on maintaining the effective cooperative relationships that are required for an increasingly complex, global, fast-paced business environment. Ariño et al. (2001) suggest that even behavior by alliance members outside the context of the alliance have an impact on the quality of the partnership.

Trust between alliance partners can serve a key role in alliance management as a substitute for formal governance structures. Barney and Hansen (1994) argue that even when there exists significant vulnerability between partners, trust permits transactions to go forward with less governance and cost than alliances where such trust does not exist. To this end, Ariño et al. (2001) suggest that alliance partners do not suspend self-interest as such but expect the joint pursuit of mutual interests will supersede private, self-seeking interests.

A number of studies have explored the importance of experience in establishing strong alliances. Evidence suggests that individuals' trust levels begin at a high level and then decrease when trust is misplaced (Klimoski \& Karol, 1976; McKnight, Cummings, \& Chervany, 1998). This suggests that effective leaders reflect on past situations when trust was either well founded or misplaced before deciding whether to form or continue an alliance with others. Roth and Schoumaker (1983) found that histories of participants influenced the outcomes of bargaining. Ariño et al. (2001) suggest that a critical determinant of the quality of the future relationship between partners is their experience with each other's behavior. A leader would have to focus on the past behavior of a partner in order to make that determination and learn from experience. Mailath and Samuelson (2001) suggest that reputations are built gradually over time. A life-cycle metaphor has been used to conceptualize the change and development of alliances (de Rond \& Bouchikhi, 2004) and suggests that learning from experience is crucial to the development of an alliance. Granovetter (1985) suggests an alliance's past dealings with a partner leads to expectations that they will be treated honestly in the future. Further research shows that firms' alliance capabilities are linked both to the amount of prior alliance experience they have had (Anand \& Khanna, 2000) and how they learned from that experience (Kale \& Singh, 1999). It is critical that leaders in alliances both recapture past events and leverage that information. 
We expect that the time orientation of leaders will play a role in how alliances are managed. The initiation of alliances, which would include both making and accepting offers, are new opportunities and would emphasize a future orientation toward time. An individual who has a strong future time perspective would be likely to seek out new opportunities for the organization and we predict that future oriented individuals will initiate alliances more often than leaders with other time orientations. We also expect that past oriented individuals will behave more cooperatively during the alliance formation, both because they will rely heavily on past experience and information about an alliance partner's history, and because they care about their reputation. Specifically, we expect to find that:

Hypothesis 1: Alliance initiation will be positively related to a player's Future Time Perspective.

Hypothesis 2: Cooperative behavior will be positively related to a player's Past-Negative Time Perspective.

Hypothesis 3: Cooperative behavior will be positively related to a player's Past-Positive Time Perspective.

Since we are predicting that individuals' different time orientations will moderate two stages of the process of alliance formation, our analysis of the relationship between each time orientation and the total score earned by an individual in the alliance game will be exploratory. However, both initiating alliances and cooperating during their formation should make a difference in success so we expect to find that:

Hypothesis 4: Cooperative behavior will be positively related to a player's level of alliance initiation.

Hypothesis 5: Total score will be positively related to a player's level of alliance initiation.

Hypothesis 6: Total score will be positively related to a player's level of cooperative behavior.

\section{METHODS}

Studying the effects of individual time perspectives and their relationship with alliance formation called for an experimental design. An experiment allowed us to create various conditions for the initiation of alliances and cooperative behavior that would have been difficult to measure otherwise. Conducting this study in the field would have required finding a sample of individuals in a sample of organizations that were concurrently entering into similar alliances. A laboratory setting allowed us to keep constant multiple factors that have been found to affect alliance formation and focus on the relationship between time perspective and successful alliance formation. The participants in our study were $108 \mathrm{MBA}$ students enrolled in strategy, human resource management and business ethics classes at an eastern university. Participation was voluntary, but all who participated in at least $75 \%$ of the rounds were awarded class credit. Twenty-five percent of the participants were full-time students and $75 \%$ were part-time students employed full-time in professional positions. Sixty-one percent were male and $31 \%$ were female.

We developed an Internet based transaction game that gave participants the opportunity to make and accept offers of alliance with other players and to choose how to manage the transaction. This was designed as an iterated version of the Prisoner's Dilemma (PD) game but, unlike Axelrod's iterated game (1984, 1997), partners varied from round to round. The game was played for twenty rounds.

\section{GAME DESIGN}

The game captured the choices players made about which partners to work with and how to manage the transactions when information about those partners was limited to reputation scores. Players interacted through alliance contracts worth 500 points in total and split between the players according to the strategy each chose for that transaction. The objective of the game was to maximize the points won over the duration of play. As in any version of the Prisoner's Dilemma (PD) game, players could choose to cooperate or defect, with varying payoffs. Our game also offered players the opportunity to purchase insurance against the chance of defection by a potential partner, so this became a four strategy version of the PD. For the payoffs associated with each strategy, see Table 1 . We note that both Defect/Insurance and Defect/No insurance are the Nash equilibriums for this game (Gibbons 1992) but that like any Prisoner's Dilemma, cooperation could result in greater joint payoffs.

Participants were introduced to the game during presentations in each class as well as e-mailings with Game instructions. Players registered for the game on-line and took a "game name" intended to preserve anonymity and to 
prevent real world reputations and side negotiations from skewing alliance decisions. We developed a pre-Game agreement that indicated that security was important and that players should not divulge their names to other students. Post-game interviews indicated that the players did maintain anonymity. Game names were drawn from noun lists for trees, birds, herbs, and so on. At registration, each participant also completed the 56 item survey that generated the time perspective factor scores.

\section{PROCEDURE}

Rounds in the game were played twice per week over the course of a semester with each round run in real time over a two day period. At the beginning of each round, $70 \%$ of the players were randomly selected based on a uniform distribution to own alliance opportunities or the right to choose an alliance partner. This was intended to assure that not all players would score in each round and competition for partners would ensue. The complete list of opportunity owners was published on the website. All players, opportunity owners or not, could sign in to the game and make offers to up to four opportunity owners (although opportunity owners could not make offers to themselves). Later, opportunity owners would sign on again and choose an alliance partner from the list of offers. There was no limit to the number of offers a player could receive but if the opportunity owner received no offers, there was no score for that round. Once an offer was accepted, the owner could accept no more offers, nor could the partner be selected as a partner by another opportunity owner in that round. After each round, we published an ordered list of players and their total scores on the website so all participants knew their relative position. See Table 1 for the scoring matrix.

Table 1: Game Payoff Matrix

\begin{tabular}{|c|c|c|c|c|c|}
\hline \multicolumn{6}{|c|}{ Player 1} \\
\hline \multirow{9}{*}{$\begin{array}{c}\text { Player } \\
2\end{array}$} & & Coop/No Insure & Coop/Insure & Defect/No Insure & Defect/Insure \\
\hline & Coop/No Insure & 250 & 200 & 500 & 450 \\
\hline & & 250 & 250 & 0 & 0 \\
\hline & Coop/Insure & 250 & 200 & 250 & 200 \\
\hline & & 200 & 200 & 200 & 200 \\
\hline & Defect/No Insure & 0 & 200 & 250 & 200 \\
\hline & & 500 & 250 & 250 & 0 \\
\hline & Defect/Insure & 0 & 200 & 0 & 200 \\
\hline & & 450 & 200 & 200 & 200 \\
\hline
\end{tabular}

In contrast to a tit-for-tat type game where players develop a history with each other (Axelrod 1984; Axelrod 1997), partner choices varied from round to round. Players did have access to information about the strategies potential partners had employed in the past. We posted a reputation score for each player that captured the number of times in the past five transactions the participant had played "cooperate". For example, a player that had cooperated four out the last five transactions would have a reputation score of 4 . Though players could learn more about potential partners by purchasing additional history, less than $1 \%$ of transactions used this option so it was not included in the analysis. The game generated over 2,400 transactions for analysis.

\section{MEASURES}

\section{Independent Variable}

The independent variable of interest was time perspective. We used the Zimbardo Time Perspective Inventory and utilized the scoring instructions published with the items (Zimbardo \& Boyd, 1999). There were 56 items on the scale including, "Even when I am enjoying the present, I am drawn back to comparisons with similar past experiences." The instrument utilized a Likert scale that ranged from (1) "very uncharacteristic" to (5) "Very characteristic." In addition, we examined student status as an independent variable. 


\section{Dependent Variables}

We tested hypotheses for three dependent variables. The first dependent variable was the initiation of alliances counted as the number of offers made and accepted. The second was the level of cooperation measured as the percentage of times the participant cooperated, rather than defected, when alliances were offered. The third dependent variable was the final score earned in the game. All hypotheses were tested in a linear regression model.

\section{RESULTS}

Table 2 shows the means, standard deviations, and correlations. Gender was initially included as a control variable but did not show any significant correlation with the variables of interest and was eliminated from the analysis.

Table 2: Descriptive Statistics and Correlations among Variables

\begin{tabular}{|c|c|c|c|c|c|c|c|c|c|c|c|}
\hline & Means & SD & $\mathbf{1}$ & $\mathbf{2}$ & $\mathbf{3}$ & $\mathbf{4}$ & $\mathbf{5}$ & $\mathbf{6}$ & $\mathbf{7}$ & $\mathbf{8}$ & $\mathbf{9}$ \\
\hline $\begin{array}{c}\text { 1. Present- } \\
\text { hedonistic }\end{array}$ & 3.08 & .46 & $(.97)$ & & & & & & & \\
\hline $\begin{array}{c}\text { 2. Present- } \\
\text { fatalistic }\end{array}$ & 2.23 & .42 & .12 & $(.96)$ & & & & & & \\
\hline $\begin{array}{c}3 . \text { Past- } \\
\text { negative }\end{array}$ & 2.66 & .60 & $-.29 * *$ & $.25 * *$ & $(.96)$ & & & & & \\
\hline $\begin{array}{c}4 . \text { Past- } \\
\text { positive }\end{array}$ & 3.75 & .73 & .14 & -.09 & $-.33 * *$ & $(.76)$ & & & & \\
\hline $\begin{array}{c}\text { 5. Future } \\
\text { 6. Student } \\
\text { status }\end{array}$ & .25 & .43 & .13 & -.03 & .04 & .04 & -.12 & 1.00 & & \\
\hline $\begin{array}{c}\text { 7. Initiation } \\
\text { of alliances }\end{array}$ & 19.77 & 6.64 & .02 & .05 & -.01 & .07 & $.20^{*}$ & $-.26 * *$ & 1.00 & \\
\hline $\begin{array}{c}\text { 8. Level of } \\
\text { cooperation }\end{array}$ & .53 & .29 & -.16 & .13 & $.22 *$ & .02 & .12 & $-.23 *$ & $.33 * *$ & 1.00 \\
\hline $\begin{array}{c}\text { 9. Total } \\
\text { score in } \\
\text { game }\end{array}$ & 4266.98 & 1619.01 & .03 & .02 & -.04 & -.02 & .16 & $-.29 * *$ & $.94 * * *$ & $.29 * *$ \\
\hline
\end{tabular}

Reliability estimates, in parentheses, are coefficient alphas.

* $\quad \mathrm{p}<.05$

$* * \mathrm{p}<.01$

$* * * \mathrm{p}<.001$

Table 3 shows the results of the regressions by dependent variable. The results supported five of the seven hypotheses. The future time-orientation factor did predict alliance formation, supporting H1, but student status was also significant. The more future oriented the participant, the more alliances that were initiated. Part-time students (who are employed full-time) were also more likely to form alliances. The past-negative factor of time perspective was significantly related to the level of cooperation but the past-positive factor was not. Thus, H3 was rejected. Again, student status was a significant predictor of cooperation. 
Table 3: Results Of Multiple Regression Analysis For Five Factors Of Time Perspective

\begin{tabular}{|c|c|c|c|c|c|c|}
\hline & $\begin{array}{l}\text { (1) Alliance } \\
\text { Initiation }\end{array}$ & & $\begin{array}{l}\text { (2) Cooper- } \\
\text { ation }\end{array}$ & & (3) Score & \\
\hline Variable & Beta & $t$ & Beta & $t$ & Beta & $\mathrm{t}$ \\
\hline $\begin{array}{c}\text { Present- } \\
\text { hedonistic }\end{array}$ & 1.41 & .94 & -0.06 & -.98 & 440.47 & 1.24 \\
\hline $\begin{array}{l}\text { Present- } \\
\text { fatalistic }\end{array}$ & 1.07 & .67 & 0.06 & .88 & 32.46 & 0.09 \\
\hline Past-negative & 0.36 & .30 & 0.10 & $2.04 *$ & -216.26 & -0.75 \\
\hline Past-positive & 0.55 & .59 & 0.04 & .93 & -167.69 & -0.77 \\
\hline Future & 2.96 & $1.97 *$ & 0.02 & .26 & 526.46 & 1.49 \\
\hline Student status & -3.84 & $-2.59 *$ & -0.94 & -1.49 & -867.52 & $-2.42 *$ \\
\hline $\begin{array}{c}\text { Alliance } \\
\text { initiation } \\
\end{array}$ & & & 0.01 & $2.97 * *$ & & \\
\hline \multirow[t]{3}{*}{ Cooperation } & & & & & 1557.18 & $2.80^{* *}$ \\
\hline & $\begin{array}{c}\mathrm{F}(5,100)= \\
2.12 *\end{array}$ & & $\begin{array}{c}\mathrm{F}(7,98)= \\
3.60 * *\end{array}$ & & $\begin{array}{c}\mathrm{F}(7,98)= \\
3.18 * *\end{array}$ & \\
\hline & $\mathrm{R}^{2}=0.11$ & & $\mathrm{R}^{2}=0.20$ & & $\mathrm{R}^{2}=0.18$ & \\
\hline
\end{tabular}

$* \mathrm{p}<.05$

$* * \mathrm{p}<.01$

None of the five factors that make up time perspective were significantly related to the final scores earned in the game. As expected, the number of alliances initiated predicted the level of cooperation, but not the total score earned in the game. However, the level of cooperation predicted the total score.

\section{DISCUSSION}

The findings provide support for the hypotheses suggesting that a person's time perspective will influence alliance formation behavior in different ways. Those with a future perspective were more likely to initiate alliances and those with a past-negative perspective were more likely to cooperate while forming alliances. A high pastpositive factor did not predict the variance in cooperation. Perhaps people who focused on past negative experiences or remembered past experiences as negative learned, the hard way, that cooperation is good. People who either had or remembered having positive experiences in the past might be less concerned about a partner defecting during alliance formation.

The results indicate partial support for the theory of Leadership and Time Orientation. This finding implies that leader tasks, which tend to become more complex at higher levels (Jaques, 1986), may require different time perspectives for different stages of each function. The implication is that leaders must be aware of their individual time perspectives, how that bias affects their behavior, and either be flexible or work closely with colleagues whose time perspectives complement theirs in order to be successful.

It appears that participants working full-time in professional positions were more likely to initiate alliances, cooperate during alliance formation, and earn more points during the alliance building game. The finding that fulltime professional experience contributes to successful alliance building is not news. However, this finding does suggests that traditional students enrolled in college full-time might behave differently in research which has implications for future management studies using students as subjects. 


\section{MANAGERIAL IMPLICATIONS}

Our results indicate that the popular and academic focus on the benefit of future-oriented leaders may be too narrow. Such leaders are adept at identifying and seizing new opportunities for the firm but may not be the most appropriate at managing the transactions that require regard for history. Put differently, we acknowledge that firms face occasions where breaks from the past, such as restructuring or developing radically new strategic directions are critical and for these, future oriented leaders are key. For example, Nokia's shift from forest and rubber products to cell phones and electronics in the 1990's reflected a perspective of "looking towards the future without the burdens of the past" (Michelsen, 2002) and for these situations, future oriented leaders are key.

Still, these situations should be rare. When the activities of the firm reflect strategic continuity, leaders must be cognizant of how today's actions are part of a larger narrative that is the basis for how others interpret what the firm will do. In these cases, leaders with a stronger past orientation may be better positioned to make the right decisions. Ultimately, we believe that effective management teams will be a blend of these perspectives which will require greater sensitivity to time orientation.

\section{LIMITATIONS}

One obvious limitation was that this study used MBA students in a game format which limits its generalizability for several reasons. First, MBA students may not yet be in positions of authority so actually creating and managing alliances in real life may elicit responses different from the ones we captured. Secondly, the game was an artificial experience which may or may not demonstrate how leaders will behave in real alliance building situations. Still, time orientation is a deeply seated psychological construct and to the extent that the students will have such opportunities in the future, our results should at least provide a guide to behavior.

A second limitation was the narrow scope of the study. By focusing only on the alliance formation process, we did not explore every facet of successful alliance building which would occur over long periods of time. The formation of alliances may begin years before they are fully realized and their success may only be measured after years of existence.

\section{FUTURE RESEARCH DIRECTIONS}

Although difficult to operationalize, future research should be done during the formation, execution, and life of real business alliances. We expect that different time perspectives are more valuable during the different stages of the process. More studies may lend support for the idea that leadership teams should ideally be made up of people with various time perspectives, thereby making an organization more effective at each stage in the process. Obviously, further research should be done on other leader responsibilities and tasks to tease out the best time perspective for each stage of each function.

To conclude, this study provides some support for the Model of Leadership and Time Orientation. It suggests that further research on time orientation and the role that it plays in leader behavior hold promise. Time orientation is currently an overlooked individual difference with potential implications for the field of leadership and organizational behavior. Bluedorn (2002) uses the analogy of time as life. He suggests that making life better is the point of studying time. We believe that making organizations and leaders better are also good reasons to study time.

\section{REFERENCES}

1. Anand, B. and Khanna, T. 2000. Do firms learn to create value? The case of alliances. Strategic Management Journal, 21: 295-315.

2. Ariño, A., de la Torre, J. and Ring, P. S. 2001. Relational quality: Managing trust in corporate alliances. California Management Review, 44: 109-131.

3. Axelrod, R. (1984). The Evolution of Cooperation. New York, Basic Books. 
4. Axelrod, R. (1997). The complexity of cooperation: Agent-based models of competition and cooperation. Princeton, NJ: Princeton University Press.

5. Barney, J. B., and Hansen, M. H. 1994. Trustworthiness as a source of competitive advantage. Strategic Management Journal, 15: 175-190.

6. Bass, B. M. 1985. Leadership and performance beyond expectations. New York: Free Press.

7. Bennis, W. and Nanus, B. 1985. Leaders: The strategies for taking charge. New York: Harper and Row.

8. Bluedorn, A. C. 2002. The human organization of time: Temporal realities and experience. Stanford, CA: Stanford University Press.

9. Bluedorn, A. C. and Denhardt, R. B. 1988. Time and organizations. Journal of Management, 14: $299-320$.

10. Burns, J. M. 1978. Leadership. New York: Harper and Row.

11. Das, T. K. 1986. The subjective side of strategy making: Future orientations and perceptions of executives. New York: Praeger.

12. Das, T. K. 1987. Strategic planning and individual temporal orientation. Strategic Management Journal, 8: 203-209.

13. Das, T. K. 1993. Time in management and organizational studies. Time and Society, 2: 267-274.

14. de Rond, M. and Bouchikhi, H. 2004. On the dialectics of strategic alliances. Organization Science, 15: 5669.

15. Drucker, P. F. 1954. The practice of management. New York: Harper and Row.

16. El Sawy, O. A. 1983. Temporal perspective and managerial attention: A study of chief executive strategic behavior. Dissertation Abstracts International, 44(05A): 1556-57.

17. Frink, D. D. and Klimoski, R. J. 1998. Toward a theory of accountability in organization and human resource management. In G. Ferris (Ed.), Research in personnel and human resources management, vol.16: 1-51. Greenwich, CT: JAI Press.

18. Gibbons, R. (1992). Game Theory for Applied Economists. Princeton, NJ, Princeton University Press.

19. Granovetter, M. 1985. Economic action and social structure: The problem of embeddedness. The American Journal of Sociology, 91: 481-510.

20. Hergert, M. and Morris, D. 1987. International collaborative agreements. Columbia Journal of World Business, 22: 15-21.

21. Hershey, P., and Blanchard, K. H. 1969. Life cycle theory of leadership. Training and Development Journal, 23: 26-34.

22. Hogarth, R. M. 1987. Judgment and choice: The psychology of decision. Chichester, England: Wiley.

23. House, R. J. 1971. A path-goals theory of leader effectiveness. Administrative Science Quarterly, 16: 321339.

24. House, R. J. 1977. A 1976 theory of charismatic leadership. In J. G. Hunt and L. L. Larson (Eds.), Leadership: The cutting edge: 189-207. Carbondale: Southern Illinois University Press.

25. Jaques, E. 1986. The development of intellectual capability: A discussion of stratified systems theory. Journal of Applied Behavioral Science, 22: 361-383.

26. Jones, J. M. 1988. Cultural differences in temporal perspectives: Instrumental and expressive behaviors in time. In J. E. McGrath (ed.), The social psychology of time: New perspectives: 21-38. Newbury Park, CA: Sage.

27. Kale, P. and Singh, H. 1999. Building alliance capabilities: A knowledge-based approach. Academy of Management Best Paper Proceedings, Chicago, IL.

28. Kale, P., Singh, H., and Perlmutter, H. 2000. Learning and protection of proprietary assets in strategic alliances: Building relational capital. Strategic Management Journal, 21: 217-237.

29. Keough, K. A., Zimbardo, P. G., and Boyd, J. N. 1999. Who's smoking, drinking, and using drugs? Time perspective as a predictor of substance use. Basic and Applied Social Psychology, 21: 149-164.

30. Kerr, S. and Jermier, J. M. 1978. Substitutes for leadership: Their meaning and measurement. Organizational Behavior and Human Performance, 22: 375-403.

31. Klimoski, R. J. and Karol, B. L. 1976. The impact of trust on creative problem-solving groups. Journal of Applied Psychology, 61: 630-633.

32. Kouzes, J. M. and Posner, B. Z. 1995. The leadership challenge: How to keep getting extraordinary things done in organizations. San Francisco: Jossey-Bass. 
33. Lewicki, R. J., McAllister, D. J., and Bies, R. J. 1998. Trust and distrust: New relationships and realities. Academy of Management Review, 23: 438-458.

34. Mailath, G. J. and Samuelson, L. Who wants a good reputation? The Review of Economic Studies, 68: 415441.

35. McKnight, D. H., Cummings, L. L., and Chervany, N. L. 1998. Initial trust formation in new organizational relationships. Academy of Management Review, 23: 473-490.

36. Michelson, Kalle 2002. Books from Finland: Talking business. The Finnish Literature Information Centre, http://dbgw.finlit.fi/fili/bff/102/nokia.htm

37. Olk, P. and Elvira, M. 2001. Friends and strategic agents: The role of friendship and discretion in negotiating strategic alliances. Group and Organization Management, 26: 124-164.

38. Ridley, M. 1996. The origins of virtue: Human instincts and the evolution of cooperation. London: Penguin.

39. Ring, P. S. and Van de Ven, A. 1992. Structuring cooperative relationships between organizations. Strategic Management Journal, 13: 483-498.

40. Roth, A. and Schoumaker, F. 1983. Expectations and reputations in bargaining: An experimental study. American Economic Review, 73: 362-372.

41. Rousseau, D. M., Sitkin, S. B., Burt, R. S., and Camerer, C. 1998. Not so different after all: A crossdiscipline view of trust. Academy of Management Review, 23: 393-404.

42. Sabel, C. F. 1993. Studied trust: Building new forms of cooperation in a volatile economy. Human Relations, 46: 1133-1170.

43. Schein, E. H. 1992. Organizational culture and leadership (2 ${ }^{\text {nd }}$ ed.). San Francisco: Jossey-Bass.

44. Thoms, P. 2004. Driven by time. Westport, CN: Praeger.

45. Thoms, P. and Blasko, D. 1999. Preliminary validation of a visioning ability scale. Psychological Reports, 85: $105-113$.

46. Thoms, P. and Greenberger, D. B. 1995. The relationship between leadership and time orientation. Journal of Management Inquiry, 4: 272-292.

47. Thoms, P. and Greenberger, D. B. 1998. A test of vision training and potential antecedents to leaders' visioning ability. Human Resources Development Quarterly, 9: 3-19

48. Tversky, A. and Kahneman, D. 1973. Availability: A heuristic for judging frequency and probability. Cognitive Psychology, 5: 207-232.

49. Vroom, V. H. and Jago, A. G. 1988. The new leadership: Managing participation in Organizations. Englewood Cliffs, NJ: Prentice-Hall.

50. Weigelt, K. and Camerer, C. 1988. Reputation and corporate strategy: A review of recent theory and applications. Strategic Management Journal, 9: 443-454.

51. Welch, J. 2001. Jack: Straight from the gut. New York: Warner Business Books.

52. Zimbardo, P. G. and Boyd, J. N. 1999. Putting time in perspective: A valid, reliable individual-differences metric. Journal of Personality and Social Psychology, 77: 1271-1288.

53. Zucker, L.G. (1987). Institutional theories of organization, Annual Review of Sociology, 13: $443-464$. 